\section{Exploring the use of stable carbon isotope ratios in short-lived leporids for local paleoecological reconstruction}

\author{
Stephen Smith, ${ }^{1}$ Raymond Mauldin, ${ }^{2}$ \\ Cynthia M. Munoz, ${ }^{2}$ Robert Hard, ${ }^{1}$ \\ Debajyoti Paul, ${ }^{3}$ Grzegorz Skrzypek, ${ }^{4}$ \\ Patricio Villanueva, ${ }^{5}$ Leonard Kemp ${ }^{6}$ \\ 'Department of Anthropology, University \\ of Texas at San Antonio; ${ }^{2}$ Center for \\ Archaeological Research, University of \\ Texas at San Antonio, TX, USA; \\ ${ }^{3}$ Department of Civil Engineering \\ (Geosciences), Indian Institute of \\ Technology, Kanpur, India; \\ ${ }^{4}$ West Australian Biogeochemistry \\ Centre, School of Plant Biology, The \\ University of Western Australia, Crawley, \\ Australia; ${ }^{5}$ Department of Geology, \\ University of Texas at San Antonio, TX; \\ ${ }^{6}$ Geo-Marine, EI Paso, TX, USA
}

\section{Abstract}

Most ecological proxies used in archaeological research operate at scales that are too coarse-grained for consideration of huntergatherer adaptive decisions. Hunter-gatherers adapt to local ecological conditions and short (e.g. seasonal, yearly) time frames. Our goal is to develop proxies to identify ecological shifts at fine-grained temporal and spatial scales for archaeological research. We use stable carbon isotope ratios $\left(\delta^{13} \mathrm{C}\right)$ in bone collagen from 58 modern leporids from two distinct ecological areas in the American Southwest as a proxy to reconstruct vegetation and climate patterns at fine-grained scales. Higher $\delta^{13} \mathrm{C}$ values in collagen of cottontail (Sylvilagus sp.) and jackrabbit (Lepus sp.) collected in the northern Chihuahuan Desert of New Mexico and West Texas suggest a more $\mathrm{C}_{4} /$ crassulacean acid metabolism (CAM) dominated local vegetation when contrasted to samples from Kerr County in Central Texas. Comparisons of temperature and precipitation patterns between the two areas, along with vegetation data, suggest that key ecological differences, reflected in the collagen isotopic compositions, are likely related to rainfall amounts and the type of green forage available to leporids, especially during winter months. Leporids in dry areas may be relying on CAM plants, including prickly pear, which has $\mathrm{a} \mathrm{C}_{4}$ isotopic signature. Alternative resources are likely to be available in wetter areas such as Central Texas.

\section{Introduction}

Reconstructions of past ecological conditions in archaeological research often rely on proxy data, such as shifts in pollen frequencies, which operate at variable spatial and temporal scales. While appropriate for many concerns, most ecological proxies operate at scales that are too coarse-grained for consideration of human adaptive decisions. Huntergatherers and agriculturalists adapt to local rather than regional ecological conditions, and to changes that occur on a seasonal or yearly time frame, not shifts that happen over centuries (Winterhalder and Leslie, 2002). Archaeologists need to develop high-resolution ecological proxies that operate at scales that are coterminous with those used by humans in making adaptive decisions.

In this paper, we explore the use of stable carbon isotope ratios $\left(\delta^{13} \mathrm{C}\right)$ of bone collagen in cottontails (Sylvilagus sp.) and jackrabbits (Lepus sp.) as potential high-resolution proxies to reconstruct vegetation and climate patterns at short-term temporal and spatial scales. We have used samples from an archaeological assemblage from Texas, USA to monitor ecological shifts (Munoz et al., 2011; Kemp, 2008) and are currently investigating other archaeological assemblages in the American Southwest. We focus on refining the application through a comparison of $\delta^{13} \mathrm{C}$ values in bone collagen $\left(\delta^{13} \mathrm{C}_{\text {collagen }}\right)$ of leporids from two distinct ecological settings. $\delta^{13} \mathrm{C}$ values of modern leporids collected in southern New Mexico and West Texas $(n=26)$ suggest that these areas have a stronger $\mathrm{C}_{4} / \mathrm{CAM}$ signature relative to those collected in Kerr County in Central Texas $(n=32)$. Comparisons of temperature and precipitation patterns between the two areas, along with vegetation transects data, suggest that key ecological differences reflected in the collagen are likely related to rainfall amounts and the type of green forage available to leporids, especially during the winter months.

As a paleoecological proxy, leoprids have several advantages. Jackrabbit and cottontail diets incorporate a variety of plants, with grasses, forbs, shrubs, and succulents consumed in response to availability, growing conditions (i.e. temperature, rainfall, and plant dormancy), and moisture content. Analyses of the stomach contents of Lepus collected in southern Arizona (Vorhies and Taylor, 1933) suggest a seasonal preference for grasses in the spring and midsummer, following rains. As grass production declines in early fall and winter, rabbits concentrate on browse consisting primarily of mesquite (Prosopis glandulosa). Cactus, such as prickly pear (Opuntia sp.) and cholla (Echinocereus fendleir), are more heavily consumed during drier months. Similar
Correspondence: Cynthia M. Munoz, Center for Archaeological Research, 1 UTSA Cir, University of Texas at San Antonio, San Antonio, 78249 TX USA.

Tel./Fax: +1.210.458.4397.

E-mail: cindy.munoz@utsa.edu

Key words: carbon isotopes, paleoecological reconstruction, leporids.

Acknowledgements: thanks to Richard Doucett and Melanie Caron [Colorado Plateau Analytical Laboratory, Nothern Arizona University (NAU), Flagstaff, AZ], to Bruce Moses who drafted the figures for this manuscript, and to the Center for Archaeological Research - The University of Texas at Sant Antonio (CAR-UTSA) staff. Kevin Daiber, Kelly Denham, and Lynn Wack of CAR helped with sample preparation. Thanks to Heath Garner of the Texas Tech University Museum (Lubbock) and Dr. Robert Baker, National Science Research Laboratory, at Texas Tech for graciously allowing us to sample their modern faunal collections. Bryant Saner provided additional modern specimens. Thanks to Dr. Mark Pollard (Archaeological Science Research Lab for Archaeology, University of Oxford) for reviewing this manuscript and to Robert Tykot [Department of Anthropology, University of South Florida (USF), Tampa, FL] for compiling and editing the Proceeding of the 2010 ISA. This research is supported by NSF grant \#0804169 awarded to Raymond Mauldin and Robert Hard. All data sets used here, as well as the samples themselves in many cases, are available through Raymond.mauldin@utsa.edu. Details on the research can be found at http://car.utsa.edu

Citation: Smith S, Mauldin R, Munoz CM, Hard R, Paul D, Skrzypek G, Villanueva P, Kemp L, 2014. Exploring the use of stable carbon isotope ratios in short-lived leporids for local paleoecological reconstruction. In: RH Tykot (ed.), Proceedings of the $38^{\text {th }}$ International Symposium on Archaeometry - May $10^{\text {th }}-14^{\text {th }} 2010$, Tampa Florida. Open Journal of Archaeometry 2:5306.

Presented at the $38^{\text {th }}$ International Symposium on Archaeometry - May $10^{\text {th }}-14^{\text {th }}$ 2010, Tampa, Florida.

This work is licensed under a Creative Commons Attribution 3.0 License (by-nc 3.0).

○C Copyright S. Smith et al., 2014

Licensee PAGEPress, Italy

Open Journal of Archaeometry 2014; 2:5306

doi:10.4081/arc.2014.5306

seasonal trends, with grasses preferred in the late spring, summer, and early fall, forbs and shrubs in the fall and winter, and shrubs and succulents in winter and early spring are reported for jackrabbits in a variety of regions (Best, 1996; Currie and Goodwin, 1966; Fatehi et al., 1988; Hayden, 1966; Hoffman et al., 1993; 
Table 1. Carbon and nitrogen isotope results from modern leporid bone collagen samples.

\begin{tabular}{|c|c|c|c|c|c|c|c|c|c|}
\hline Laboratory & CAR-ref & Genus & Area & Collection date & $\delta^{13} C^{*}$ & Carbon (\%) & $\delta^{15} \mathrm{~N}$ & Nitrogen (\%) & Replicates** \\
\hline NAU & 709.1 & Lepus & 1 & Spring 2009 & -17.3 & 45.3 & 6.1 & 15.9 & 1 \\
\hline NAU & 710.1 & Lepus & 1 & Spring 2009 & -15.8 & 43.4 & 11.1 & 15.7 & 1 \\
\hline $\mathrm{NAU}$ & 711.1 & Lepus & 1 & Spring 2009 & -17.2 & 44.8 & 5.6 & 16.3 & 1 \\
\hline NAU & 712.2 & Lepus & 1 & Spring 2009 & -18.8 & 44.4 & 6.3 & 15.8 & 1 \\
\hline $\mathrm{NAU}$ & 713.1 & Lepus & 1 & Spring 2009 & -19.7 & 43.2 & 7.0 & 15.4 & 1 \\
\hline $\mathrm{NAU}$ & 714.1 & Lepus & 1 & Spring 2009 & -20.0 & 43.5 & 8.9 & 15.4 & 1 \\
\hline NAU & 715.1 & Lepus & 1 & Spring 2009 & -19.9 & 44.6 & 8.7 & 15.8 & 1 \\
\hline $\mathrm{NAU}$ & 744.1 & Lepus & 1 & Spring 2009 & -17.1 & 39.7 & 6.7 & 14.1 & 2 \\
\hline Geochron & na & Lepus & 1 & 07-06-1991 & -15.3 & na & na & na & 2 \\
\hline Geochron & na & Lepus & 1 & 19-10-1991 & -16.9 & na & na & na & 3 \\
\hline Geochron & na & Lepus & 1 & 16-09-1991 & -17.3 & na & na & na & 1 \\
\hline Geochron & na & Lepus & 1 & 18-10-1991 & -16.7 & na & na & na & 1 \\
\hline Geochron & na & Lepus & 1 & 12-11-1991 & -21.3 & na & na & na & 1 \\
\hline Geochron & na & Lepus & 1 & 28-06-1991 & -13.3 & na & na & na & 1 \\
\hline Geochron & na & Lepus & 1 & 16-09-1991 & -16.9 & na & na & na & 1 \\
\hline Geochron & na & Lepus & 1 & 04-06-1992 & -19.2 & na & na & na & 1 \\
\hline $\mathrm{NAU}$ & 359.1 & Sylvilagus & 1 & Spring 2009 & -19.5 & 39.5 & 6.1 & 13.6 & 2 \\
\hline NAU & 361.1 & Sylvilagus & 1 & Spring 2009 & -18.9 & 35.5 & 6.5 & 12.2 & 1 \\
\hline $\mathrm{NAU}$ & 362.1 & Sylvilagus & 1 & Spring 2009 & -19.9 & 39.5 & 7.0 & 13.9 & 1 \\
\hline $\mathrm{NAU}$ & 363.1 & Sylvilagus & 1 & Spring 2009 & -21.1 & 40.3 & 5.8 & 14.2 & 1 \\
\hline $\mathrm{NAU}$ & 364.1 & Sylvilagus & 1 & Spring 2009 & -16.4 & 40.8 & 5.7 & 14.5 & 1 \\
\hline $\mathrm{NAU}$ & 365.1 & Sylvilagus & 1 & Spring 2009 & -19.9 & 42.1 & 5.5 & 14.8 & 1 \\
\hline $\mathrm{NAU}$ & 366.1 & Sylvilagus & 1 & Spring 2009 & -19.8 & 42.7 & 6.6 & 15.1 & 1 \\
\hline $\mathrm{NAU}$ & 367.1 & Sylvilagus & 1 & Spring 2009 & -19.9 & 41.9 & 5.7 & 14.8 & 1 \\
\hline NAU & 368.1 & Sylvilagus & 1 & Spring 2009 & -18.5 & 42.2 & 6.0 & 15.1 & 1 \\
\hline $\mathrm{NAU}$ & 369.1 & Sylvilagus & 1 & Spring 2009 & -16.2 & 41.3 & 5.8 & 14.4 & 1 \\
\hline NAU & 356.1 & Lepus & 2 & 24-02-2008 & -15.2 & 40.5 & 7.5 & 13.6 & 1 \\
\hline $\mathrm{NAU}$ & 743.1 & Lepus & 2 & 29-08-2009 & -15.7 & 40.7 & 6.5 & 13.9 & 3 \\
\hline NAU & 799.1 & Lepus & 2 & 14-05-1997 & -23.4 & 41.0 & 3.7 & 14.6 & 1 \\
\hline $\mathrm{NAU}$ & 810.1 & Lepus & 2 & 20-05-1999 & -17.6 & 40.6 & 2.8 & 14.5 & 1 \\
\hline $\mathrm{NAU}$ & 815.1 & Lepus & 2 & 14-05-1998 & -23.3 & 43.2 & 1.8 & 15.1 & 1 \\
\hline $\mathrm{NAU}$ & 816.1 & Lepus & 2 & 14-05-1996 & -19.3 & 41.4 & 5.3 & 14.5 & 1 \\
\hline $\mathrm{NAU}$ & 817.1 & Lepus & 2 & 14-05-1997 & -23.2 & 41.4 & 3.0 & 14.6 & 1 \\
\hline $\mathrm{NAU}$ & 819.1 & Lepus & 2 & 14-05-1998 & -22.2 & 40.8 & 2.3 & 14.1 & 1 \\
\hline $\mathrm{NAU}$ & 820.1 & Lepus & 2 & 14-05-1996 & -20.6 & 41.4 & 2.5 & 14.5 & 2 \\
\hline NAU & 826.1 & Lepus & 2 & 20-05-1996 & -17.9 & 42.3 & 5.2 & 14.8 & 1 \\
\hline $\mathrm{NAU}$ & 828.1 & Lepus & 2 & 14-05-1997 & -18.7 & 42.2 & 3.6 & 14.8 & 1 \\
\hline NAU & 830.1 & Lepus & 2 & 17-05-1998 & -20.6 & 41.3 & 3.6 & 14.6 & 2 \\
\hline $\mathrm{NAU}$ & 831.1 & Lepus & 2 & 16-05-1996 & -16.2 & 41.1 & 3.2 & 14.6 & 1 \\
\hline NAU & 833.1 & Lepus & 2 & 14-05-1998 & -21.7 & 37.5 & 4.3 & 12.8 & 1 \\
\hline NAU & 835.1 & Lepus & 2 & 13-05-1998 & -20.4 & 43.2 & 3.8 & 15.1 & 1 \\
\hline NAU & 857.1 & Lepus & 2 & 20-05-1999 & -22.3 & 41.4 & 2.8 & 14.9 & 1 \\
\hline $\mathrm{NAU}$ & 360.1 & Sylvilagus & 2 & 03-06-2009 & -17.5 & 39.7 & 4.0 & 14.1 & 1 \\
\hline NAU & 519.1 & Sylvilagus & 2 & 16-05-1996 & -20.7 & 40.1 & 2.3 & 14.5 & 2 \\
\hline $\mathrm{NAU}$ & 797.1 & Sylvilagus & 2 & 16-05-1996 & -17.6 & 41.4 & 8.3 & 14.2 & 1 \\
\hline $\mathrm{NAU}$ & 801.1 & Sylvilagus & 2 & 21-05-1996 & -18.4 & 40.5 & 2.7 & 14.5 & 1 \\
\hline NAU & 803.1 & Sylvilagus & 2 & 15-05-1997 & -24.3 & 41.2 & 2.0 & 14.6 & 1 \\
\hline $\mathrm{NAU}$ & 805.1 & Sylvilagus & 2 & 20-05-1996 & -21.2 & 39.8 & 2.6 & 14.2 & 1 \\
\hline $\mathrm{NAU}$ & 811.1 & Sylvilagus & 2 & 14-05-1998 & -23.4 & 39.8 & 2.5 & 13.8 & 1 \\
\hline NAU & 814.1 & Sylvilagus & 2 & 16-05-1996 & -20.4 & 39.7 & 5.7 & 13.6 & 1 \\
\hline $\mathrm{NAU}$ & 818.1 & Sylvilagus & 2 & 13-05-1996 & -18.0 & 42.6 & 4.9 & 15.0 & 1 \\
\hline$\overline{\mathrm{NAU}}$ & 821.1 & Sylvilagus & 2 & 14-05-1996 & -21.5 & 41.5 & 3.1 & 14.4 & 1 \\
\hline NAU & 822.1 & Sylvilagus & 2 & 20-05-1996 & -21.8 & 42.1 & 3.2 & 14.9 & 1 \\
\hline NAU & 823.1 & Sylvilagus & 2 & $12-05-96$ & -20.8 & 42.9 & 3.6 & 15.3 & 1 \\
\hline NAU & 827.1 & Sylvilagus & 2 & $14-05-97$ & -20.9 & 41.2 & 3.1 & 14.1 & 1 \\
\hline $\mathrm{NAU}$ & 832.1 & Sylvilagus & 2 & $20-05-96$ & -21.9 & 39.9 & 2.8 & 13.9 & 1 \\
\hline NAU & 834.1 & Sylvilagus & 2 & $20-05-96$ & -20.9 & 40.3 & 3.0 & 13.8 & 1 \\
\hline $\mathrm{NAU}$ & 860.1 & Sylvilagus & 2 & $16-05-96$ & -17.8 & 42.3 & 5.1 & 14.7 & 1 \\
\hline
\end{tabular}

CAR-ref, Center for Archaeological Research-reference; NAU, Nothern Arizona University; Geochron, Geochron Laboratories (Chelmsford, MA, USA); na, not available. *Analytical uncertainties (l $\sigma$ standard deviation) for $13 \mathrm{C}$ data at NAU are $\leq 0.10 \%$; ** when present replicate results were averaged. 
MacCraken and Hansen, 1984; Sparks, 1968; Uresk, 1978; Westoby, 1980). Cottontails have a similar pattern. Turkowski (1975) looked at the stomach content of 97 cottontails from Maricopa County in southern Arizona collected over 16 months. In terms of dietary bulk, grasses (37.9\%) and forbs (41.3\%) were the most commonly consumed plant groups, with 43 plant species identified as dietary items over the study period. Strong seasonal patterns, with increased grass consumption in the summers, and increased consumption of succulents or other moisture rich plants during dry periods, were also present in cottontails (Hoffman et al., 1993; MacCraken and Hansen, 1984; Turkowski, 1975; Brown, 1947; Chapman et al., 1982; deCalesta, 1979; Riegel, 1942; Scribner and Krysl, 1982).

Cottontail and jackrabbits occupy small lifetime home ranges. Their dietary signature should reflect the local vegetation. While there are reports of movements of small numbers of Lepus in excess of $5 \mathrm{~km}$ (e.g. Smith et al., 2002), most jackrabbits spend their lives within an area less than $1 \mathrm{~km}^{2}$ in size, with most estimates falling below 170 ha (Best, 1996; Farias et al., 2006; French et al., 1965; Lechleitner, 1958; Smith, 1990). Cottontails have even smaller lifetime home ranges. Chapman et al. (1982) and Trent and Rongstad (1974) summarise studies that suggest home ranges less than 15 ha for a variety of Sylvilagus species (Haugen, 1942).

Leporids have short lives. In most cases, their dietary signature reflects a temporal span of less than two years. Tiemeier and Plenert (1964) found that only 9 of 906 jackrabbits in southern Kansas were more than three years of age (French et al., 1965; Feldhamer, 1979). Ingles (1941), in a study of $S$. audubonii in
California, notes that only seven of 29 rabbits (ca. 24\%) survived after a single year, with 19 months being the maximum age observed (Chapman et al., 1982; Allen, 1939; Bronson and Tiemeier, 1958).

Critically, the short-term, local vegetation patterns present in leporid diets should produce distinct ${ }^{13} \mathrm{C}_{\text {collagen }}$ values (Munoz et al., 2011). Experimental studies suggest that the $\delta^{13} \mathrm{C}$ of herbivore bone collagen reflects the carbon isotopic composition of the diet and, in turn, the vegetation type. Collagen values are about 5\%o heavier than diet (DeNiro and Epstein, 1978; Tykot, 2004). As vegetation changes, either on a seasonal basis or directionally over time, different mixes of $\mathrm{C}_{3}\left(\delta^{13} \mathrm{C}\right.$ range of -33 to $-23 \% 0), \mathrm{C}_{4}\left(\delta^{13} \mathrm{C}\right.$ range of -16 to $-9 \% 0$ ) and crassulacean acid metabolism (CAM) (most range between -10 and -20\%0) plants will be present in many instances

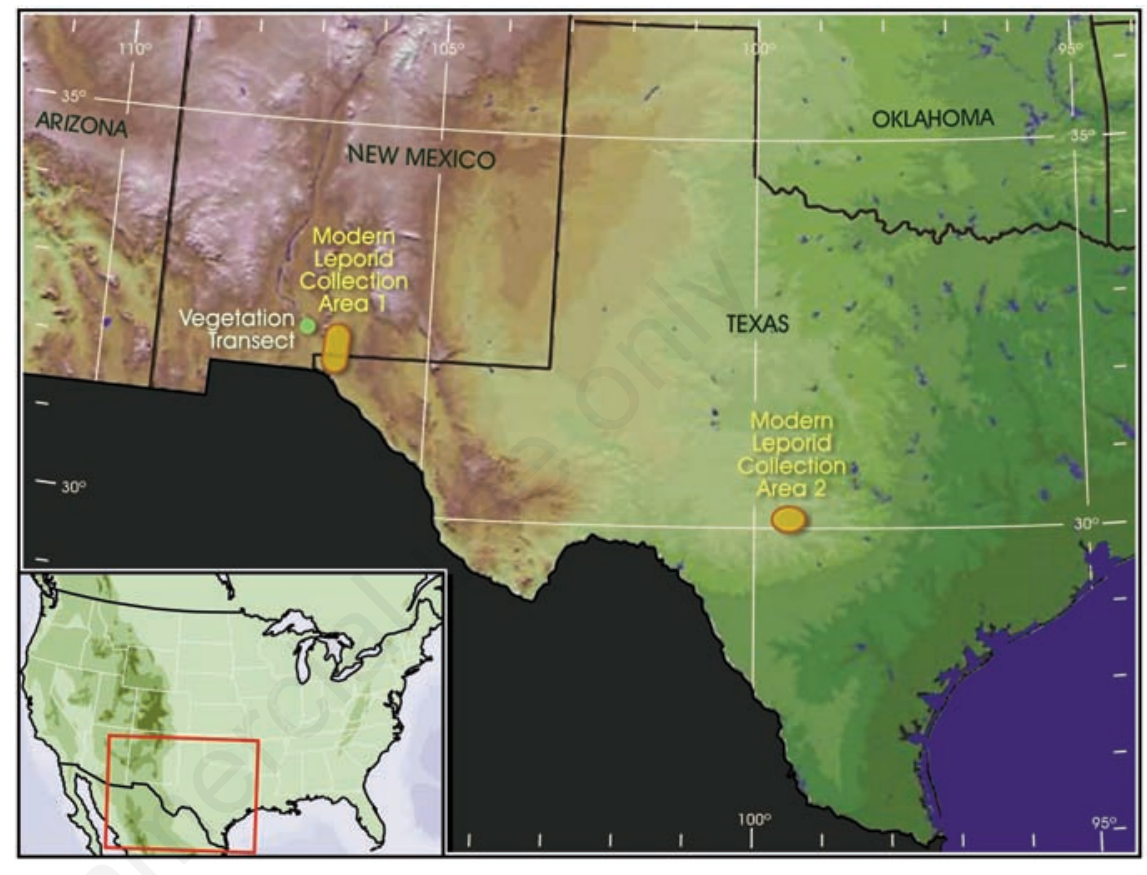

Figure 1. Map of Southwestern United States showing locations of modern leporid collection areas. Area 1 includes portions of El Paso County, Texas, and Dona Ana County, New Mexico. Area 2 is in Kerr County, Texas. Also shown is the location of the vegetation transect adjacent to Area 1.

Table 2. Carbon and nitrogen isotopic values for prickly pear (Opuntia sp.) stems from Texas counties.

\begin{tabular}{|c|c|c|c|c|c|}
\hline County & Latitude (N) & Longitude (W) & Replicates & $\delta^{13} \mathrm{C}(\% 0)$ & $\delta^{15} \mathrm{~N}(\% 0)^{*}$ \\
\hline Lubbock & $33^{\circ} 37^{\prime} 12^{\prime \prime}$ & $101^{\circ} 53^{\prime} 12^{\prime \prime}$ & 1 & -12.1 & 2.2 \\
\hline Hamilton & $31^{\circ} 56^{\prime} 17^{\prime \prime}$ & $98^{\circ} 04^{\prime} 07^{\prime \prime}$ & 1 & -11.2 & 2.9 \\
\hline Tom Green & $31^{\circ} 41^{\prime} 30^{\prime \prime}$ & $100^{\circ} 46^{\prime} 50^{\prime \prime}$ & 1 & -11.6 & 4.0 \\
\hline Lampasas & $31^{\circ} 24^{\prime} 24^{\prime \prime}$ & $98^{\circ} 10^{\prime} 25^{\prime \prime}$ & 1 & -13.2 & 5.9 \\
\hline Burnett & $30^{\circ} 49^{\prime} 08^{\prime \prime}$ & $98^{\circ} 13^{\prime} 34^{\prime \prime}$ & 1 & -12.5 & 4.4 \\
\hline Blanco & $30^{\circ} 18^{\prime} 51^{\prime \prime}$ & $98^{\circ} 24^{\prime} 32^{\prime \prime}$ & 1 & -12.8 & 2.6 \\
\hline Kendall & $29^{\circ} 53 ’ 33^{\prime \prime}$ & $98^{\circ} 38^{\prime} 36^{\prime \prime}$ & 1 & -11.7 & 1.5 \\
\hline Kendall & $29^{\circ} 53 ’ 29^{\prime \prime}$ & $98^{\circ} 38^{\prime} 37^{\prime \prime}$ & 1 & -12.0 & 3.4 \\
\hline Kendall & $29^{\circ} 53 ’ 27^{\prime \prime}$ & $98^{\circ} 38^{\prime} 37^{\prime \prime}$ & 1 & -12.5 & 1.5 \\
\hline Bexar & $29^{\circ} 34^{\prime} 49^{\prime \prime}$ & $98^{\circ} 37^{\prime} 54^{\prime \prime}$ & 7 & -12.6 & 2.8 \\
\hline Atascosa & $28^{\circ} 57^{\prime} 45^{\prime \prime}$ & $98^{\circ} 35^{\prime} 01^{\prime \prime}$ & 1 & -13.0 & 4.2 \\
\hline McMullen & $28^{\circ} 36^{\prime} 17^{\prime \prime}$ & $98^{\circ} 33^{\prime} 02^{\prime \prime}$ & 1 & -12.6 & 7.8 \\
\hline McMullen & $28^{\circ} 13^{\prime} 51^{\prime \prime}$ & $98^{\circ} 30^{\prime} 48^{\prime \prime}$ & 1 & -12.0 & 7.4 \\
\hline Kleberg & $27^{\circ} 17^{\prime} 55^{\prime \prime}$ & $97^{\circ} 49^{\prime} 19^{\prime \prime}$ & 1 & -12.9 & 4.9 \\
\hline
\end{tabular}

*Analytical uncertainties ( 1 standard deviation) for $\delta^{15} \mathrm{~N}$ data at Nothern Arizona University are $\leq 0.20 \%$. 
(Bender, 1968; 0'Leary, 1988; Smith and Epstein, 1970). Given the wide diet of leporids, these different mixes of $\mathrm{C}_{3}, \mathrm{C}_{4}$, and CAM plants should produce different ${ }^{13} \mathrm{C}_{\text {collagen }}$ values, depending on the proportions of these plants in the diet. For example, on the American Great Plains researchers have shown that increased summer rainfall in the context of sufficient temperatures should produce both more $\mathrm{C}_{4}$ grass and may increase the length of time that grass is available (Epstein et al., 1997; Paruelo and Lauenroth, 1996). The $\delta^{13} \mathrm{C}$ of leporid bone collagen would reflect that shift. However, details between leporid collagen, vegetation regimes, and climate parameters are not well defined. Here we contrast collagen values derived from leporids in two locations that have different climate and vegetation regimes to better define the associated impacts.

\section{Materials and Methods}

Jackrabbit and cottontail samples used in this analysis were collected from two locations in the American Southwest (Figure 1). Leporid collection Area 1 is located in far west Texas (El Paso County) and southern New Mexico (Dona Ana County) in the northern Chihuahuan Desert, east of El Paso, Texas $\left(32^{\circ} 00^{\prime} \mathrm{N} / 106^{\circ} 15^{\prime} \mathrm{W}\right)$. Eight jackrabbits were collected from this area in late 1991 and 1992 (Mauldin, 1993). Eight additional samples were collected in the spring of 2009 , along with 10 cottontails. Leporid Collection Area 2 is located in Kerr County in Central Texas (Figure 1; $30^{\circ} 05^{\prime} \mathrm{N} / 99^{\circ} 30^{\prime} \mathrm{W}$ ). Twenty-nine samples were collected between 1996 and 1999, with three additional leporids collected during 2008 and 2009.

All samples from Area $1(\mathrm{n}=26)$, as well as the three most recent leporids samples gathered from Area 2, were collected as carcasses. For selected limbs, bones were broken and boiled to remove adhering tissue. Boiling also removes lipids (Ugan and Coltrain, 2011). The remaining 29 samples from Area 2 were recovered from museum collections at Texas Tech University. These samples were clean and dry at the time of our acquisition. The eight Area 1 samples collected in the early 1990 s were analysed for $\delta^{13} \mathrm{C}$ collagen by Geochron Laboratories (Krueger, 1992). All other samples $(n=50)$ were prepared at the Center for Archaeological Research (CAR) at the University of Texas at San Antonio (UTSA) following methods developed by Longin and Ambrose (Longin, 1971; Ambrose, 1990), Hdescribed by Munoz and others (Munoz et al., 2011). The carbon isotope ratios ( $\delta^{13} \mathrm{C}$ values), along with the percentage of $\mathrm{C}$ and $\mathrm{N}$ in the leporid collagen samples, were measured

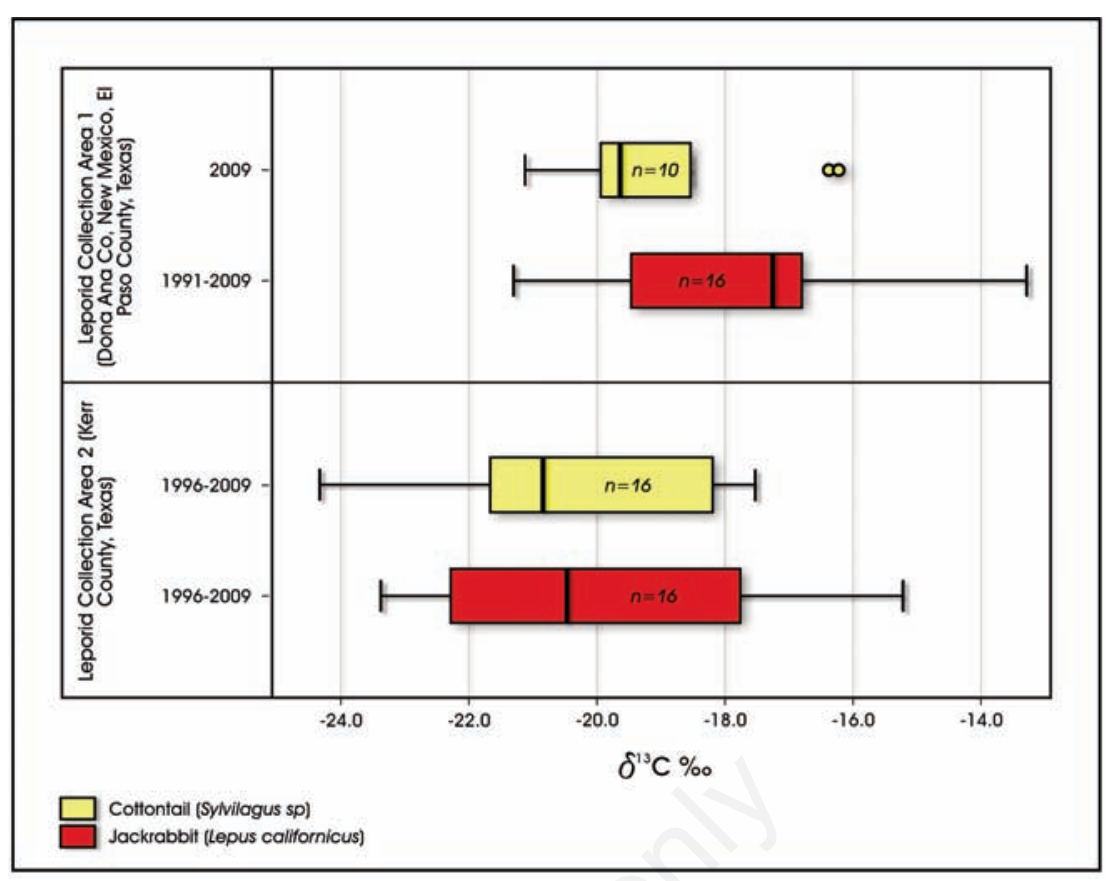

Figure 2. Box plots of $\delta^{13} \mathrm{C}$ collagen values from modern Sylvilagus sp. (yellow) and Lepus (red) by collection areas shown in Figure 1. A test of medians and comparison of distributions in Statistical Package for Social Science Version 19 show no significant difference between cottontail and jackrabbits (Area 1, $n=26$; median test statistic=2.60, significance=.226; Mann-Whitney $U$ statistic $=107$, significance $=.155$; Area 2, $n=32$; median test statistics $=2.00$; significance $=.157$; Mann-Whitney $U$ statistic $=142$, significance=.598). Comparisons of cottontail $\delta^{13} \mathrm{C}$ collagen values $(n=26)$ between the two areas showed no significant differences in distributions (Mann-Whitney $U$ statistic $=45$, significance $=.065$ ), but significant differences in medians (test statistic $=5.85$, significance $=.041$ ). Comparisons of jackrabbit $\delta^{13} \mathrm{C}$ collagen median values were not significant $(n=32$; median test statistic $=2.00$, significance $=.157)$, but distributions were significantly different (Mann-Whitney $U$ statistic $=67$, significance $=.022)$.

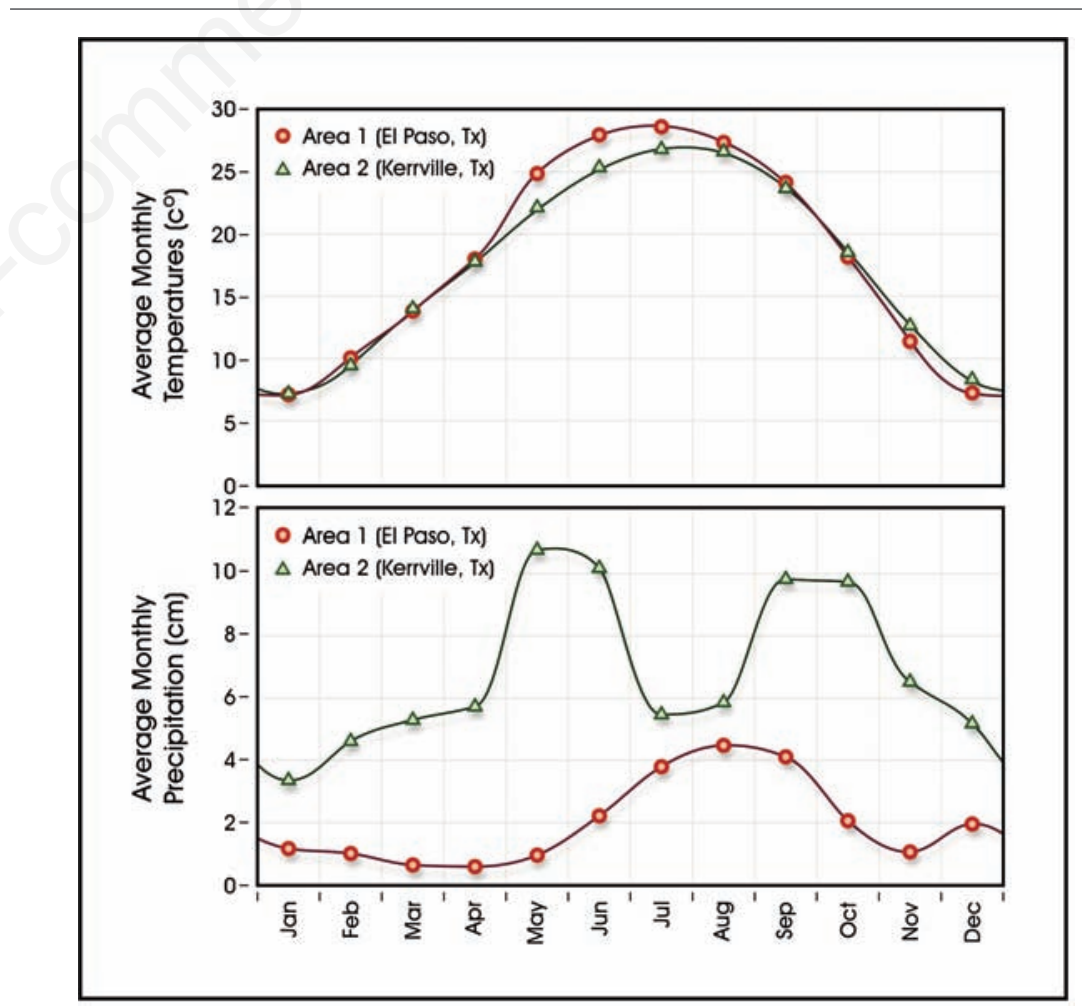

Figure 3. Average monthly temperature (top) and precipitation (bottom) values by area based on 1971-2000 records (44). Area 1 values are from El Paso International Airport (station ID 412797); Area 2 values are from Kerrville, Texas (station ID 414782). 
using either a Carlo Erba NC2100 Elemental Analyzer or Costech ECS4010 Elemental Analyzer (Costech Analytical Technologies Inc., Valencia, CA, USA) attached on-line with a Thermo Finnigan Delta ${ }^{\text {plus }}$ XP Stable Isotope Ratio Mass Spectrometer (IRMS) at the Colorado Plateau Analytical Laboratory, Northern Arizona University (NAU). All $\delta^{13} \mathrm{C}$ values are reported in permil relative to the VPDB scale.

For the 50 NAU samples, the weight percent nitrogen ranges from 12.21 to $16.26 \%$ with percent carbon falling between 35.5 and $45.27 \%$
(Table 1). The atomic ratio of carbon to nitrogen is between 3.21 and 3.48. These ratios are consistent with good collagen integrity (Ambrose and Norr, 1992). The percent carbon and nitrogen values were not obtained for the eight Area 1 samples collected in the early 1990s. While Table 1 provides the $\delta^{15} \mathrm{~N}$ values for the remaining 50 samples, the focus of our discussion is on variation in carbon isotopes and their relationship with vegetation and climate parameters. Causes of $\delta^{15} \mathrm{~N}$ variability in leporids are not well understood. Resent work on jackrabbits (Ugan and Coltrain, 2011) sug-

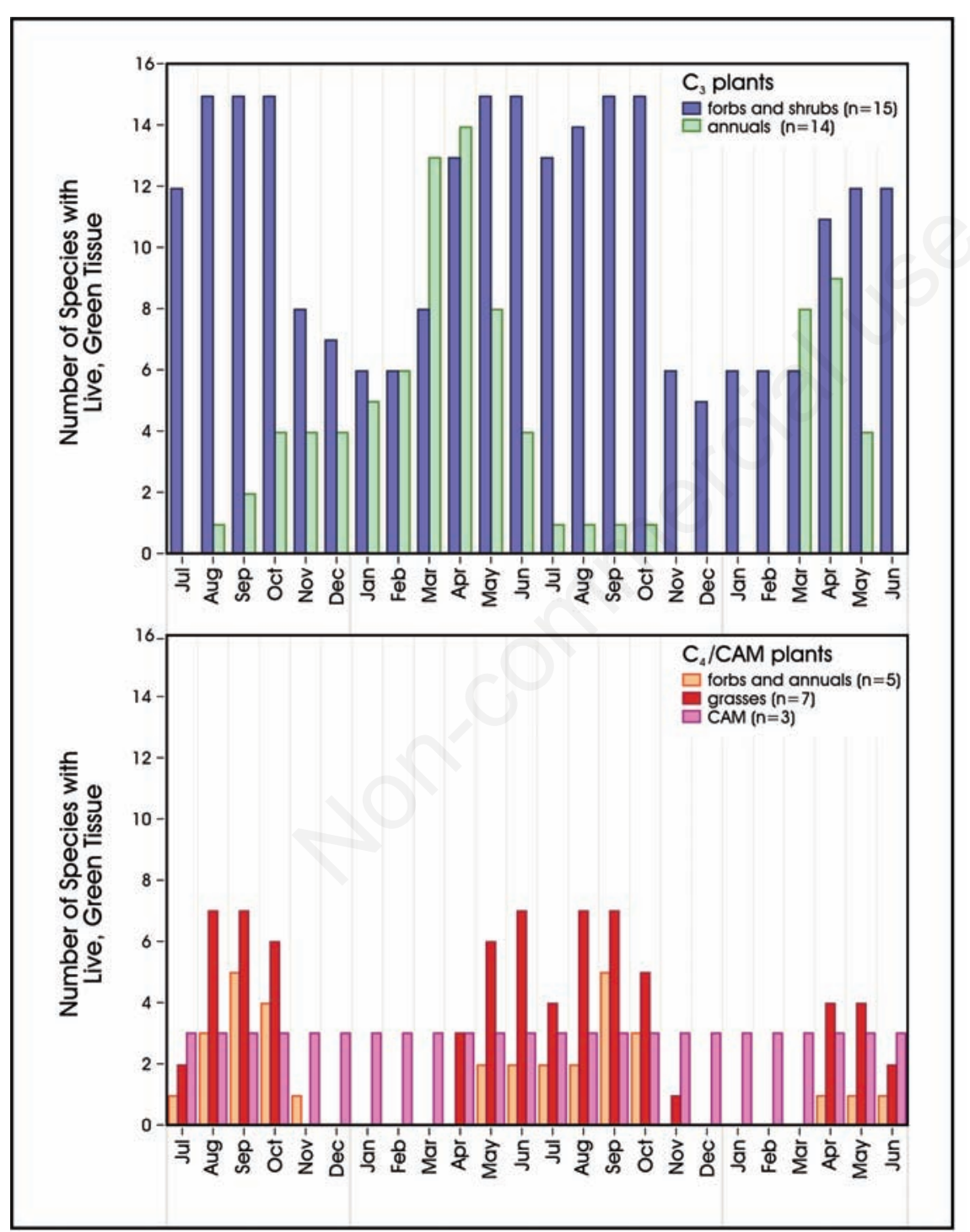

Figure 4. Montlhy shifts in the number of species with live, green, above-ground tissue between July 1978 and June 1980 along a vegetation transect adjacent to Area 1. Data are from Kemp (1983) and include the 44 most abundant species. Forbs, shrubs, and annuals using a C3 photosynthetic pathway are grouped in the top bar graph, while $\mathrm{C} 4$ forbs, annuals and grasses are grouped with the crassulacean acid metabolism species in the bottom graph. Note that the values for December and January are estimated based on adjacent months and trends in the dataset. gests that $\delta^{15} \mathrm{~N}$ variability is primarily related to factors such as topography and soil salinity rather than directly reflecting climate variables (Ugan and Coltrain, 2011).

\section{Results and Discussion}

Table 1 provides the $\delta^{13} \mathrm{C}$ values for the 58 samples, identified by genus and location (see Figure 1). $\delta^{13} \mathrm{C}_{\text {collagen }}$ of jackrabbit samples $(\mathrm{n}=32)$ ranges from -23.38 to $-13.30 \%$ with an average value of $-18.79 \%$. Cottontail $\delta^{13} \mathrm{C}_{\text {collagen }}$ values $(\mathrm{n}=26)$ range from -24.33 to $-16.23 \% 0$ (average $=-19.90 \%$ ), suggesting slightly higher proportions of $\mathrm{C}_{3}$ plants in their diet. Histograms (not shown) suggest that the cottontail $\delta^{13} \mathrm{C}_{\text {collagen }}$ values approximate normality, but the Lepus values are left skewed. As such, we focus on non-parametric comparisons.

Figure 2 presents box plots of $\delta^{13} \mathrm{C}_{\text {collagen }}$ values for each genus by collection areas (see Figure 1). Compared with cottontails, jackrabbit $\delta^{13} \mathrm{C}_{\text {collagen }}$ values are more positive in both locations, with differences of $2.38 \%$ in Area 1 median values and $0.37 \%$ in Area 2 medians. However, comparison of jackrabbits and cottontail medians (median test) as well as distributions (Mann-Whitney U) failed to show statistically significant differences. Comparison of $\delta^{13} \mathrm{C}_{\text {collagen }}$ values across the two areas by genus does show statistically significant differences on some variables. While the distributions of $\delta^{13} \mathrm{C}_{\text {collagen }}$ values for cottontails are not statistically different between areas (sig.=.065), median values are significantly different (sig.=.041). For jackrabbits, distributions of $\delta^{13} \mathrm{C}_{\text {collagen }}$ values between areas are significantly different (sig.=.022), but median values are not (sig.=.157). Overall, leporids in Area 1 clearly have a collagen signature that reflects more consumption of $\mathrm{C}_{4}$ and $\mathrm{CAM}$ plants relative to Area 2.

Monthly temperature and rainfall data (Figure 3) for two stations located within 30 $\mathrm{km}$ of the centers of Areas 1 and 2 show major differences in rainfall between the two areas (NOAA, 2004). The yearly Area 2 rainfall total $(82.75 \mathrm{~cm})$ is roughly 3.5 times that of Area 1 $(23.95 \mathrm{~cm})$. Area 2 has higher average rainfall in every month, with dramatic differences in the spring/summer and early fall during the growing season (Figure 3). Vegetation densities should be dramatically different between the two areas. While we lack information on specific plant growth patterns in Area 2, Figure 4 uses data in Kemp (1983) to monitor monthly vegetation changes in live, green tissue of the 44 most abundant plants along a transect west of Area 1 (Figure 1). Plants with green tissue are likely to be part of the leporid diet because of their higher moisture content 
(Uresk, 1978; Westoby, 1980). C 3 plants are dominant during all periods (Figure 4, top panel). Production is highest during the late spring through the early fall. Availability of $\mathrm{C}_{3}$ plants declines over the late fall and winter months, though some $\mathrm{C}_{3}$ shrubs are present throughout the year. The seven types of $\mathrm{C}_{4}$ grasses, $C_{4}$ forbs $(n=2)$ and $C_{4}$ annuals $(n=3)$ are present only during the summer/early fall (Figure 4, bottom panel), probably in response to summer precipitation and temperatures (Figure 3). CAM plants, consisting here of prickly pear, cholla, and yucca (torreyi), are available year round and do not fluctuate in response to short-term rainfall or temperature shifts (Figure 4, bottom panel).

Linking the isotopic patterns in Figure 2 to the vegetation and climate patterns shown in Figures 3 and 4 are difficult given the lack of detailed vegetation data from Area 2. Clearly, the Area 1 vegetation data suggests that CAM resources may play an important seasonal dietary role. This is supported by a study on the impact of the grazing habits of rabbits on prickly pear in a region $35 \mathrm{~km}$ north of Area 1 (Hoffman et al., 1993). That study shows two periods of heavy prickly pear stem use by leporids, with one feeding period occurring in June and a second during the months of December, January, and February. While reasons for the June feeding are unclear, the winter feeding spike correlates with a low number of alternative plants (Figure 4) and dry conditions (Figure 3). Moisture stress and low winter resource availability are unlikely in Area 2 given the greater precipitation and similarity in fall, winter, and spring temperatures. Compared to the $\delta^{13} \mathrm{C}_{\text {collagen }}$ of leporids in Area 2, higher values for Area 1 (Figure 2) may be related to increased Area 1 use of resources such as prickly pear. CAR-UTSA has processed and analysed, through NAU, samples from 14 prickly pear plants located in 11 Central and South Texas counties (Table 2). Stem $\delta^{13} \mathrm{C}$ values range from -11.22 to $-13.17 \%$ (average=$12.35 \% 0)$. These values are consistent with other studies of prickly pear (e.g. Eickmeir and Bender, 1976). Dietary intake of these succulents on a seasonal basis (Hoffman et al., 1993) will result in higher $\delta^{13} \mathrm{C}_{\text {collagen }}$ values like those seen in the Area 1 samples.

\section{Conclusions}

A comparison of $\delta^{13} \mathrm{C}$ values in bone collagen $\left(\delta^{13} \mathrm{C}_{\text {collagen }}\right)$ of modern leporids from southern New Mexico and West Texas suggest that these areas have a stronger $\mathrm{CAM} / \mathrm{C}_{4}$ signature (mean $-18.20 \%$; $n=26$ ) relative to Kerr County in Central Texas (mean -20.17\%0; $\mathrm{n}=32$ ). Temperature and precipitation pat- terns, along with vegetation transects data, suggest that key ecological differences reflected in the collagen are likely related to the different type of green forage available to leporids resulting from different amounts of rainfall, especially during the winter months. While research is ongoing into these relationships, ${ }^{13} \mathrm{C}_{\text {collagen }}$ in modern leporid bone does track ecological differences in these two environments. This suggests that the ${ }^{13} \mathrm{C}_{\text {collagen }}$ in leporid bone can be used as a high-resolution ecological proxy in archaeological research.

\section{References}

Allen DL, 1939. Michigan cottontails in winter. J Wildlife Manage 3:307-22.

Ambrose SH, 1990. Preparation and characterization of bone and tooth collagen for isotopic analysis. J Archaeol Sci 17:431-51.

Ambrose SH, Norr L, 1992. On stable isotopic data and prehistoric subsistence in the Soconusco region. Curr Anthropol 33:4014.

Bender MM, 1968. Mass spectrometric studies of carbon-13 variations in corn and other grasses. Radiocarbon 10:468-72.

Best TL, 1996. Lepus californicus. Mamm Species 530:1-10.

Bronson FH, Tiemeier OW, 1958. Reproduction and age distribution of black-tailed jack rabbits in Kansas. J Wildlife Manage 22:409-14.

Brown HL, 1947. Coaction of jack rabbit, cottontail, and vegetation in a mixed prairie. Trans Kans Acad Sci 50:28-44.

Chapman JA, Hockman JG, Edwards WR, 1982. Cottontails. In: J.A. Chapman, G.A. Feldhamer, (eds.) Wild mammals of North America: biology, management, and economics. The Johns Hopkins University Press, Baltimore, pp. 83-123.

Currie P, Goodwin DL, 1966. Consumption of forage by black-tailed jackrabbits on saltdesert ranges of Utah. J Wildlife Manage 30:304-11.

deCalesta DS, 1979. Spring and summer foods of audubon's cottontail rabbit (Sylvilagus audubonii) in North-Central Colorado. Southwest Nat 24:549-53.

DeNiro MJ, Epstein S, 1978. Influence of diet on the distribution of carbon isotopes in animals. Geochim Cosmochim Ac 42:495506.

Eickmeir WG, Bender MM, 1976. Carbon isotope ratios of crassulacean acid metabolism species in relation to climate and phytosociology. Oecologia 25:341-7.

Epstein HE, Lauenroth WK, Burke IC, Coffin DP, 1997. Productivity patterns of C3 and C4 functional types in the U.S. Great Plains. Ecology 78:722-31.
Farias V, Fuller TK, Cervantes FA, Lorenzo C, 2006. Home range and social behavior of the endangered Tehuantepec jackrabbit (Lepus flavigularis) in Oaxaca, Mexico. J Mammal 87:748-56.

Fatehi M, Pieper RD, Beck RF, 1988. Seasonal food habits of blacktailed jackrabbits (Lepus Californicus) in Southern New Mexico. Southwest Nat 33:367-70.

Feldhamer GA, 1979. Age, sex ratios, and reproductive potential in black-tailed jackrabbits. Mammalia 43:473-8.

French NR, McBride R, Detmer J, 1965. Fertility and population density of the black-tailed jackrabbit. J Wildlife Manage 29:14-26.

Haugen A, 1942. Home range of the cottontail rabbit. Ecology 23:354-67.

Hayden P, 1966. Food habits of black-tailed jack rabbits in Southern Nevada. J Mammal 47:42-6.

Hoffman MT, James CD, Kerley GIH, Whitford WG, 1993. Rabbit herbivory and its effect on cladode, flower and fruit production of Oputia Violacea Var Macrocentra (Cactaceae) in the Northern Chihuahuan desert, New Mexico. Southwest Nat 38:309-15.

Ingles LG, 1941. Natural history observations on the audubon cottontail. J Mammal 22:227-50.

Kemp PR, 1983. Phenological patterns of Chihuahuan desert plants in relation to the timing of water availability. $\mathrm{J}$ Ecol 71:427-36.

Kemp L, 2008. Buffaloed by bison: modeling bison abundance in prehistoric central Texas. MA Thesis. The University of Texas at San Antonio ed., TX, USA.

Krueger HW, 1992. Stable isotope ratio analysis of modern jackrabbit bone samples. Krueger Enterprises Inc. ed., Geochron Laboratory Division, Billerica, MA, USA.

Lechleitner RR, 1958. Movements, density, and mortality in a black-tailed jack rabbit population. J Wildlife Manage 22:371-84.

Longin R, 1971. New model of collagen extraction for radiocarbon dating. Nature 230:241-2.

MacCraken JG, Hansen RM, 1984. Seasonal foods of blacktail jackrabbits and nuttall cottontails in Southeastern Idaho. J Range Manage 37:256-9.

Mauldin RP, 1993. Exploring the potential of variation in jackrabbit carbon isotopic signatures as an indicator of seasonality on archaeological sites in the Chihuahuan desert. Office of Environmental Management ed., Washington, DC, USA, p. 31.

Munoz CM, Mauldin RP, Paul D, Kemp L, 2011 (in press). Monitoring paleovegetation shifts through stable carbon isotope variability in archaeologically recovered lep- 
orids. Tex J Sci 63.

NOAA, 2004. Climatography of the United States No. 20, Monthly Station Climate Summaries, 1971-2000. National Oceanic and Atmospheric Administration ed., Washington, DC, USA.

0'Leary MH, 1988. Carbon isotopes in photosynthesis. BioScience 38:328-36.

Paruelo JM, Lauenroth WK, 1996. Relative abundance of plant functional types in grasslands and shrublands of North America. Ecol Appl 6:1212-24.

Riegel A, 1942. Some observations of the food coactions of rabbits in Western Kansas during periods of stress. Trans Kans Acad Sci 45:369-75.

Scribner KT, Krysl LJ, 1982. Summer foods of the audobons cottontail (Sylvilagus auduboni: leporidae) on Texas Panhandle Playa Basins. Southwest Nat 27:460-3.

Smith BN, Epstein S, 1970. Two categories of $13 \mathrm{C} / 12 \mathrm{C}$ ratios of higher plants. Plant Physiol 47:380-4.

Smith GW, 1990. Home range and activity pat- terns of black-tailed jackrabbits. Great Basin Nat 50:249-56.

Smith GW, Stoddart LC, Knowlton FF, 2002. Long-distance movements of black-tailed jackrabbits. J Wildlife Manage 66:463-9.

Sparks DR, 1968. Diet of black-tailed jackrabbits on Sandhill Rangeland in Colorado. J Range Manage 21:203-8.

Tiemeier OW, Plenert ML, 1964. A comparison of three methods for determining the age of black-tailed jackrabbits. J Mammal 45:409-16.

Trent TT, Rongstad OJ, 1974. Home range and survival of cottontail rabbits in Southwestern Wisconsin. J Wildlife Manage 38:459-72.

Turkowski FJ, 1975. Dietary adaptability of the desert cottontail. J Wildlife Manage 39:748-56.

Tykot RH, 2004. Stable isotopes and diet: you are what you eat. In: M. Milazzo, M. Piacentine (eds.) Proceedings of the International School of Physics "Enrico Fermi" Course CLIV. IOS Press,
Amsterdam, pp. 433-44.

Ugan A, Coltrain J, 2011. Variation in Collagen stable nitrogen values in black-tailed jackrabbits (Lepus californicus) in relation to small-scale differences in climate, soil, and topography. J Archaeol Sci 38:1417-29.

Uresk DW, 1978. Diets of the black-tailed hare in steppe vegetation. J Range Manage 31:439-42.

Vorhies CT, Taylor WP, 1933. The life histories and ecology of jack rabbits, Lepus Alleni and Lepus Californicus ssp., in relation to grazing in Arizona. University of Arizona College of Agriculture ed., Tucson, AZ, USA.

Westoby M, 1980. Black-tailed jack rabbit diets in Curlew Valley, Northern Utah. J Wildlife Manage 44:942-8.

Winterhalder B, Leslie PW, 2002. Risk-sensitive fertility: the variance compensation hypothesis. Evol Hum Behav 23:59-82. 